\title{
Hydropower Development Plans and Progress in Lao PDR ${ }^{1}$
}

\section{Xaypaseuth Phomsoupha}

\begin{abstract}
Laos is a mountainous country with very favorable conditions of hydropower development. Rainfall is considered high. It has $26,000 \mathrm{MW}$ of theoretical potential. The Laos Govt. has a strategy to use hydropower to eradicate poverty. It has continuously made numbers of agreements with the neighboring country Thailand, Vietnam and Cambodia for increased power export. The companies developing and exporting hydropower also has a system to include importing company as equity share holder of the company. It will supply $7000 \mathrm{MW}$ and $5000 \mathrm{MW}$ to Thailand and Vietnam respectively by 2020. It has set a target to increase domestic electrification from present $60 \%$ to $90 \%$ by 2020 . The participation of private sector is sought and promoted through Build -Own- OperateTransfer approach. The exports of power sector amounts to 30\% of all Laos export Levels.
\end{abstract}

Key words: Hydro power development in Laos, IPP projects in Laos

\section{Introduction}

$\mathbf{T}$ he Lao People's Democratic Republic (Lao PDR or Laos) is a mountainous landlocked country endowed with natural resources. Its territory covers substantial part of the Mekong River basin. Around 35\% of total inflows of the Mekong River are contributed by main tributaries that are scattered through the territory of Laos. As the country intercepts monsoons from two directions - from the Gulf of Thailand and the GulfofTonkin-precipitation is considerably high and favorable for hydropower development. This presents an opportunity for Laos to develop hydropower plants to meet its domestic electrification needs and also to export electricity to neighboring countries where demand for electric power has been steadily increasing.

In June 1993, the Government of the Lao People's Democratic Republic (the "GOL") and the Government of the Kingdom of Thailand signed the first Memorandum of Understanding (MOU) to support the development of power projects in the Lao PDR through the supply of up to 1,500 MW of electricity to Thailand. To accommodate the steady increase in demand for electricity in Thailand the two Governments have extended the MOU several times up to December 2007 when the most recent agreement saw the power purchase scheme expanded to cover the supply of 7000 MW of electric power to Thailand by 2020.

In 1998, the Government of Laos also signed a MOU with the Government of Vietnam covering the development of power projects in Lao PDR for the supply of $2000 \mathrm{MW}$ of electric power to Vietnam. In December 2006 the two Governments signed a second MOU that resulted in the agreed supply of electricity being increased from $2000 \mathrm{MW}$ to 3000 MW by 2015 . Then, in January 2008, a further increase, from $3000 \mathrm{MW}$ to $5000 \mathrm{MW}$ for the supply of electricity by 2020 , was agreed in principle.

The power sector in Lao PDR serves two vital national priorities: (i) it promotes economic and social advancement by providing a reliable and affordable domestic power supply; and (ii) it earns foreign exchange from electricity exports.

The Lao Government's plans for the power sector involve rapid and simultaneous development on several fronts with a view to:

- Expanding the generation, transmission, distribution and off-grid development to increase the electrification ratio for the country from current level of about $60 \%$ to a target of above $90 \%$ by 2020 ;

- Increasing government revenues from independent power plants (IPP) export investments and honoring power export commitments with Thailand and Vietnam by promoting a development carried out by private sector;

- Promoting $500 \mathrm{kV}$ grid development within the Greater Mekong Sub-region (GMS) to integrate the power systems of Lao PDR and its neighbors.

Scarcity of finance for investment in power generation has been presenting a bottleneck in the development plans for the sector. Historically, financing needs have met by International Financial Institutions (IFIs) but their support for generation has been limited in recent years. The participation of the private sector has therefore been sought and promoted through a Build-Own-Operate-Transfer (BOOT) approach.

The power sector, and especially hydropower, is now an important contributor to Lao PDR's economic growth and national poverty reduction effort, and the exports in this sector amount to approximately 30\% of all Lao PDR's export levels.

\section{Development progress}

Electricity from hydropower plants was not produced in Lao PDR until the late 1960s. Some small hydro-electric plants ranging from $50 \mathrm{KW}$ to $5 \mathrm{KW}$ serving small isolated local grids in different parts of the country were commissioned. By contrast, today the electricity sector is the third largest export earner for the country. It has been estimated that the country has the potential to generate about 26,000 MW through the application of hydropower; the current levels of generating capacity developed constitute only $3 \%$ of this potential. Before 1993 only three hydropower plants had been developed and brought into operation. The power sector was 
subsequently opened up to foreign investment and there are now nine hydropower plants in the country in operation and a further seven projects are under construction:

\section{IPP Projects in operation}

1. Houay Ho Hydropower Project (150 MW) achieved its commercial operation date in 1998. Investment by Suez Energy of Belgium (60\%), HHTC of Thailand (20\%) and Electricité du Laos (20\%). Debt financing was raised from international private banks. Of the generated energy, 98\% is supplied to Electricity Generating Authority of Thailand (EGAT) with a take-or-pay commitment for 30 years-period.

2. Theun-Hinboun Hydropower Project (210 MW) achieved its commercial operation date in 1999. Direct shareholder investment in this project represented $30 \%$ of total project cost while the remaining $70 \%$ was raised from international private banks. Electricité du Laos (EdL) holds $60 \%$ of shares and each of GMS of Thailand and the Nordic Group of Scandinavian countries has 20\%. A take-or-pay Power Purchase Agreement (PPA) was signed and entered into by and between Theun-Hinboun Power Company Limited (THPC) and Electricity Generating Authority of Thailand to supply electricity to EGAT's grid for a period of 30 years from the commercial operation date.

As a consequence of the economic recession in the late 1990 demand for electricity in Thailand was static for a period. As a result, several IPP projects in Laos were delayed or suspended during this period of economic crisis. When the demand for electricity started to pick up again in 2002, the IPP development in Lao PDR was back on track.

\section{IPP Projects under construction}

1. Nam Theun 2 Hydropower Project (1080 MW) achieved Financial Close on 15 June 2005. The total project cost of US $\$ 1250$ million is divided into equity and debt financing, representing 30\% and $70 \%$ respectively. Nam Theun 2 Power Company Limited (NTPC) was established under Lao PDR law, being the owner of the Project. Shareholders having shares in NTPC are the Lao Holding State Enterprise (25\%), Electricity Generating Public Company Limited (25\%), Electricité de France International (35\%) and Italian-Thai Development Public Company Limited (15\%). Being involved in the financing of the Project are 26 international banks including international financial institutions such as the World Bank, the Asian Development Bank, the European Investment Bank, Agence Française de Développement, etc. The Project resettled around 6,00o indigenous people, mostly various ethnic minority peoples, who were living in the assigned reservoir area. In order to share information and gain support from the local public and international communities, a series of domestic consultations and international communications were launched during the project preparation phase. The
Nam Theun 2 Project is now well advanced and is set to achieve its power-on date by 15 December 2009.

2. Nam Ngum 2 Hydropower Project ( 615 MW) achieved its financial close on 1 July 2006. EdL, holding $25 \%$ of total shares, represents the Government of Lao PDR in the Project. Financing of the Project is of limited recourse. The project involves the resettlement of around 6000 people. Significantly, the experience and practices gained from the Nam Theun 2 Project have been substantially tailored and adapted for application on the Nam Ngum 2 Project. The Project is due to start supplying electricity to EGAT in 2011.

3. Xe Kaman 3 Hydropower Project (250 MW) is the first Lao project to supply electricity to Electricity of Vietnam (EVN). Financial close was achieved in April 2006. The Project is currently under construction.

4. Nam Lik 1.2 Hydropower Project (100 MW) is a BOOT project with investment by China Water and Energy Corporation (CWE) holding 90\% of the shares and EdL 10\%. All generated energy will be used to supply domestic needs. The project is scheduled for commercial operation in May 2010.

5. Nam Ngum 5 Hydropower Project (120 MW) is a joint investment by Sinohydro Corporation from China having a 95\% shareholding and EdL holding $5 \%$ of total shares. The project will start supplying the EdL grid by 2010.

6. Nam Nhone Hydropower Project (2.5 MW) is the first Small Power Plant (SPP) project, being jointly developed by Lao and French private investors. The project will supply the EdL grid in Bokeo, a northern province of Laos.

7. Theun-Hinboun Expansion $(220+60$ MW) jointly invested by Electricite du Laos (EdL) that holds 60\% of shares and each of GMS of Thailand and the Nordic Group of Scandinavian countries has 20\%. The Project will supply $60 \mathrm{MW}$ and $220 \mathrm{MW}$ to EdL and EGAT respectively in 2011.

\section{Hydropower Projects owned by EdL under construction}

Se Xet 2 Hydropower Project (76 MW) is being developed by EdL for the supply of electricity to meet domestic load demand in the south of the country.

\section{Development plans}

Following the implementation of the MOUs that were signed with the Government of Thailand and the Government of Vietnam, a numbers of projects have been studied in respect of feasibility, social and environmental impact studies. IPP projects that export energy to neighboring countries are required to set aside at least $10 \%$ of total installed capacity for the supply of electricity to the local market.

\section{Plans to supply to Thailand}

Concession agreements and power purchase agreements 
have been finalized for the projects listed below. These projects are in the pipeline, aiming at achieving financial close by the end of 2008 and then supplying electricity to Thailand as scheduled. Projects in this category are:

1. Nam Ngum 3 Hydropower Project ( 440 MW) is a joint development by MDX Co Ltd of Thailand, Marubeni Corporation (Japan), EGCO (Thailand) and Lao Holding State Enterprise (LHSE). The project is scheduled for its commercial operation in 2013;

2. Nam Ngiep 1 Hydropower Project (262 MW) is a joint investment by Kansai Electrics (Japan), EGAT International (Thailand) and LHSE (Laos). 2014 is anticipated date for commercial operation.

3. Nam Theun 1 Hydropower Project (520 MW) is being jointly developed by Gamuda Berhad (Malaysia), EGCO (Thailand) and LHSE (Laos). March 2013 has been set for commercial operation.

4. Nam Ou Hydropower Project (110o MW) is a development being headed by Sinohydro Corporation of China. The developer is in discussions with EGCO (Thailand) to join the investment as a strategic partner. The project is planned to achieve commercial operation by 2013 .

5. Hongsa Lignite-Fired Power Project (180o MW) is the only non-hydropower project being developed in Lao PDR to date. The Project is expected to be energized in 2013.

\section{Plans to supply to Vietnam}

The Xe Kaman 1 Hydropower Project with its installed capacity of $468 \mathrm{MW}$ is the most advanced project following the start of construction of the Xe Kaman 3 Hydropower Project that commenced in 2006. Other hydropower projects such as the Sekong Hydropower Project $3 \mathrm{~A}$ and $3 \mathrm{~B}$, with installed capacities of $152 \mathrm{MW}$ and $96 \mathrm{MW}$ respectively, are under study. A further study, of the Dak Emeule Hydropower Project having an installed capacity of $138 \mathrm{MW}$, is due to be finalized by the end of 2008 .

\section{Plans to supply to Cambodia}

So far, thereis no specific hydropowerprojectbeing developed for the supply of electricity to Cambodia. But, in December 2007 Electricite du Cambodge (EdC) and Electricite du Laos (EdL) signed a power purchase agreement whereby EdL will supply around 10 MW from its southern grid to meet small load demand centers in Cambodia. In the meantime, there was an agreement in place between the two governments for the supply of 200 MW from Laos to Cambodia by 2020.

\section{Plans for domestic supply}

In addition to the $10 \%$ of total capacity that was to be made available for local supply through the IPP export projects, several medium size IPP projects have been nominated by the Lao government for development to meet demand in the country.

Xaypaseuth PHOMSOUPHA, graduated with a Masters Degree in Development Administration at the Australian National University in Canberra. During his 23-year career Mr. Xaypaseuth has also completed a series of overseas formal training courses in legal disciplines and in financing. He was first involved in the power sector as project analyst in 1991. Subsequently, he was appointed as Chief Secretary of the Lao National Committee for Energy (LNCE) in 1996. In his current position as Director General of Energy Promotion \& Development in the Lao Ministry of Energy and Mines, he is directly responsible for drafting and negotiating legal documents for non-recourse financing in the Lao power sector. During his career he has been involved in non-recourse financing negotiations within the power sector involving two IPP projects that are now supplying electricity to Thailand and several others that are currently under construction. Presently he is the lead negotiator heading up the government-investor negotiation team to negotiate the concession agreements, power purchase agreements and credit facilities agreements of IPP projects to supply electricity to the domestic grid, as well as to Thailand, Cambodia and Vietnam.

Corresponding address: xaypaseuth@laopdr.com

\section{Notes}

1 This article was previously published by the Department of Energy Promotion and Development, Ministry of Energy and Mines, Vientiane, Lao PDR, at www.poweringprogress. org (July 2008).

\section{References}

DEPD, 2008 (February), Power plants in Lao PDR, Vientiane, Laos: Department of Energy Promotion and Development.

Maunsell/AECOM, 2006 (June), IPP Development and Institutional Restructuring, Vientiane, Laos: Department of Energy Promotion and Development.

Phomsoupha, Xaypaseuth, 1995, Impact of Foreign Direct Investment on Public Sector Reform: The case of investment in electric power sector, Canberra: Australian National University. 